\title{
FISCAL SUSTAINABILITY AND ECONOMIC GROWTH: A CASE STUDY OF UTTAR PRADESH IN THE 21ST CENTURY
}

\author{
Dr. Sumedha Pandey \\ Assistant Professor, Department of Economics, C.M.P. Degree College, Prayagraj, \\ Uttar Pradesh.
}

Article DOI: https://doi.org/10.36713/epra8344 DOI No: 10.36713/epra8344

\begin{abstract}
Fiscal sustainability refers to the maintenance of public finances within an affordable and serviceable limit by rationalising debt and deficits within tolerable limits. India, since the time of independence has been taking assistance of debt and deficits to meet its shortages in revenue for the purpose of development and growth. For quite a long time, the concept of fiscal prudence was not given due importance of its role in ensuring long-term sustainable growth. It was only after the major economic crisis of 1990s, that several reforms were initiated targeting at longer duration targets. As a part of series of these reforms, FRBM Act was implemented in 2003 to keep a check on the fiscal indicators of the country especially the revenue deficit, fiscal deficit and debt-GDP ratio to contain the situation of growing fiscal indiscipline. The act was implemented both at the Centre and State level. It has almost been a decade and a half since its implementation. In the course of this duration, some states focused more on the growth parameters while other states focused more on the fiscal sustainability which in turn will initiate growth according to the ideology behind it. The present study specifically makes an analysis of the policies adopted by the state of Uttar Pradesh to establish fiscal sustainability. An investigation has been done to evaluate whether fiscal sustainability measures have adversely affected the growth of the state? The study concludes that although Uttar Pradesh is the most populous and one of the largest state, area wise, it could not create an investment atmosphere for investors due to lack of infrastructure and other facilities because of its focus on fiscal sustainability.
\end{abstract}

KEYWORDS: Fiscal Sustainability, FRBM Act, debt-GSDP ratio, fiscal deficit, interest payments.

\section{OVERVIEW}

In economic theory Lord Keynes brought a revolutionary change when he declared that fiscal policy be used for economic growth of a nation with stability, as monetary policy has a very limited role especially in extreme situations where it is rendered useless. Moreover, monetary policy is also limited as it can only impact demand side of an economy while fiscal policy can be utilised in both areas i.e., aggregate supply and aggregate demand. Before Keynesian revolution, Classicals believed that the role of government is very limited and either surplus or at the most balanced budget policy should be adopted. They always cautioned against public debt while Keynes argued that even public debt if used rationally can lead to economic growth. According to Keynes, government can adopt all measures (tax revenue, non-tax revenue, deficit financing, public debt and helicopter money) to enhance public expenditure for the production of public goods, merit goods as well as other forward linking social overhead projects for growth. All emerging developing and even developed countries used the Keynesian fiscalism for their growth with high dose of deficit financing and public debt. India, like many other countries (between 1947 to 1960) followed Keynesian principle of government intervention for rapid industrialisation and economic growth. Most developing countries of Latin America, Africa, South Asia as well as developed countries like North America, Canada followed this policy successfully in 1950s and 1960s. One must remember that during this period of the 20th century, global GDP and global trade rose tremendously.

During 1970s and 1980s, two different kinds of problem began to rise for different nations. On one hand, all Latin American countries faced the problem of unsustainable public debt. Most Latin American countries fell into the debt trap (25\% of export earning used for interest payments). Mexico, Argentina, Brazil, Uruguay, Paraguay had to pay $50 \%$ or more of their export earnings as interest payments. Their domestic debt was also unsustainable. On the other hand, US and European countries began to face high inflation due to high monetized 
deficit. Many economists like Milton Friedman, Taylor started questioning the Keynesian system which led to problems of high inflation. This led economists to rethink about Keynesian policies and the conclusion was that fiscal sustainability is a precondition of economic growth as well as price stability.

International institutions like IMF, World Bank, OECD group through many empirical analyses, found that Keynesian policy of deficit could be adopted but with certain limits. The concept of fiscal deficit, primary deficit, revenue deficit became the buzzword of symposia and conferences. In 1980s and 1990s, IMF, World Bank group of institutions suggested (on the basis of Williamson or Washington consensus) that overall fiscal deficit shall not be more than 3\% in normal circumstances. A study of OECD countries found that most of the countries of OECD group are also not following the fiscal sustainability lessons and are having high fiscal deficit of 5\% and above. The G20 finance ministers and central bank governors meeting was held at Saint Andrews, Scotland in 2009 to 'put on the breaks' on fiscal deficit so that growth with stable price could be achieved and sustained.

\section{INDIAN ECONOMY}

Indian economy grew slowly during first 30 years of planning (1950-80) even though it followed Keynesian fiscal policy of high deficits which led to high inflation between 1970 to 1990s. In the earlier periods of planning unlike Latin American countries, India did not opt for unlimited foreign borrowings. So, although there was high inflation but India avoided debt trap. In 1980s, India started inviting foreign borrowings for rapid growth. One must remember that between 1960 to 1980 most of Indian foreign loan was in the form of foreign aid from World Bank group institutions and had not taken commercial loans. It began with IMF loan of US $\$ 5.2$ billion in 1982-84 and later India also opted for commercial loan both public and private. India nearly entered in debt trap in 1990s in terms of foreign borrowings as nearly $24 \%$ of export income was used in interest payment. Public debt was also quite high as almost $40 \%$ of total public revenue was spent in interest payment. The eighth and ninth finance commission suggested India to opt for fiscally sustainable policy both at Centre and State level. Finally, government of India on $26^{\text {th }}$ August, 2003 enacted FRBM act which commenced from $5^{\text {th }}$ July, 2004.

The enactment of FRBM act was necessitated by the fact that in most developing countries as public revenue from tax and non-tax sources was quite low and government not only had to provide public goods and funds for economic growth but also for various populistic measures, coupled with policies for capture groups, electoral cycles and incentives to be provided for various economic and non-economic activities. This becomes very difficult in the period of adverse business cycles. Thus, deficits become a rule rather than exception. Throughout 1990s even with robust growth, Indian economy maintained high level of fiscal, primary and revenue deficits leading to unsustainable foreign and public debt as mentioned above. To contain fiscal deficit, strengthen transparent fiscal management and for a better consistency in macroeconomic policies, the FRBM act, 2003 was adopted. One must remember that it is almost impossible to curtail expenditure at one go, therefore, the $3 \%$ target of fiscal deficit for centre was to be followed in medium term. Another important point to remember here is that deficits of national governments are different from deficits of state governments. Centre has full control over monetary policy and foreign debts. It has more manoeuvrability than states which can borrow from central bank and public only. So, state deficits can result only in debt unsustainability while Centre's deficit impacts price stability as well as foreign exchange stability. Thus, the deficits of States shall not be compared with that of Centre and most studies in OECD countries discuss in detail the impacts of deficit at national level. But FRBM act of India was simultaneously implemented for Centre and States. Government of India adopted FRBM as an act for well-defined, transparent, simple, nominal anchor which could be enforceable and independently monitored. The FRBM act anchors of India did raise some important questions such as (a) Is $3 \%$ fiscal deficit limit sustainable in all conditions? i.e., pro-cyclical and anti-cyclical or in normal conditions and pandemic conditions? (b) Do all states have similar economic performance index so that one nominal anchor could be applied to all the states (one shoe fits all)? (c) Is revenue surplus always required? (d) How can even a low debt be sustainable if economy is in negative or zero growth rate zone? In this research paper the basic issue discussed is limited to, economic growth and sustainability of fiscal deficit in case of Uttar Pradesh although comparison with India has been done to highlight the issue.

\section{LITERATURE REVIEW}

The debate on fiscal sustainability is now more than 60 years old. Most countries of Latin America, Africa and Asia gained independence between 1950 and 1960. At the time of independence most were agricultural countries with low per capita income, low tax base and primitive technology. In order to grow at a rapid rate, they followed theories of Rosenstein Rodan, Lewis, Leibenstein, Singer and Hirschman which suggested huge investment in industry, infrastructure and manufacturing. To achieve high growth rate, high dose of public expenditure was required so they tried to maximise public revenue from all possible sources such as tax, non- 
tax, high import duties, high deficit and high public debt (internal and external). For a decade these methods did help but with rising amortisation bill most developing countries were forced to take loan to pay the interest on past loans (debt trap). At this time various committees and commissions began to discuss the importance of fiscal sustainability. A brief review of literature is presented below to analyse the research gap for the present paper.

In the backdrop of global recession of 2008, the report titled, 'Restoring Fiscal Sustainability: Lessons for the Public Sector' by OECD (2009), analysed the need of fiscal consolidation for sustainable growth of economies. Emphasizing the need of planned exit strategies to move out of the claws of fiscal imbalances, the report suggests these strategies to work for a particular time frame to derive fruitful results.

Article, 'Productive government expenditure and fiscal sustainability' by R. Arai (2011) discusses the relationship between public spending and productivity using theoretical foundations of Overlapping-Generations Model. Public spending to GDP ratio has been taken as a parameter to measure debt sustainability.

Assessing fiscal sustainability in selected OECD economies, the paper 'Interest-rate-growth differentials and government debt dynamics' by D Turner and Francesca Spinelli, OECD (2012) undertakes a panel estimation to find out the scenario of this differential and the reasons behind it, in order to give some future policy recommendations. For majority of OECD economies, this differential has found to be low and the basic reason stated behind this has been low inflation targeting by monetary policy.

'Fiscal policy and long-term growth' IMF Policy Paper, 2015 identifies the role of fiscal policy in determining medium-term to long-term growth of developed and developing nations. It suggests that structural tax and expenditure reforms can promote economic growth.

V. Akram and Badri Narayan Rath (2019), in their article titled, 'Fiscal sustainability in India: evidence from Markov Switching and thresholds regression models' analysed the issue of fiscal sustainability by doing a time series quarterly analysis since 1997 to 2013. Using the Markov-Switching-Vector Error Correction Model it is concluded that low fiscal deficit periods favour fiscal sustainability and public debt beyond an optimum level of $21 \%$ of GDP on quarterly basis, hurts economic growth.

'How far can India stretch its fiscal deficit to support economic growth?' by D.K. Srivastava, September 2020, Economy Watch analyses the level of fiscal deficit that may be tolerated by Indian economy at the time of Covid pandemic. It suggests that bringing fiscal deficit back to the target may take some time and this process should be gradual.

Debt Sustainability Monitor (2021), Institutional Paper by European Commission provides an analysis of the fiscal sustainability challenges being faced by EU member nations in light of the Covid pandemic and makes a comparative analysis from 2019 to suggest measures to lessen the debt sustainability risk being faced by member countries.

Chapter 2 of Economic Survey 2020-21, 'Does Growth lead to Debt Sustainability? Yes, But not vice-versa!' discusses the growth and fiscal sustainability debate in Indian context to conclude that growth brings fiscal sustainability but the opposite may not be true as interest rate paid on debt in India has been less than the growth rate not by exception but by rule.

\section{UTTAR PRADESH'S ECONOMY}

Uttar Pradesh is one of the largest states of India with a population of more than 25 crores. In population it generally surpasses more than 180 countries of the world. The per capita GSDP of Uttar Pradesh is among the lowest in India along with Bihar and Odisha. 
Figure 1: Per Capita NNI (India) \& Per Capita NSDP (U.P.)

$$
\text { PER CAPITA NNI (INDIA) \& PER CAPITA NSDP (U.P.) }
$$

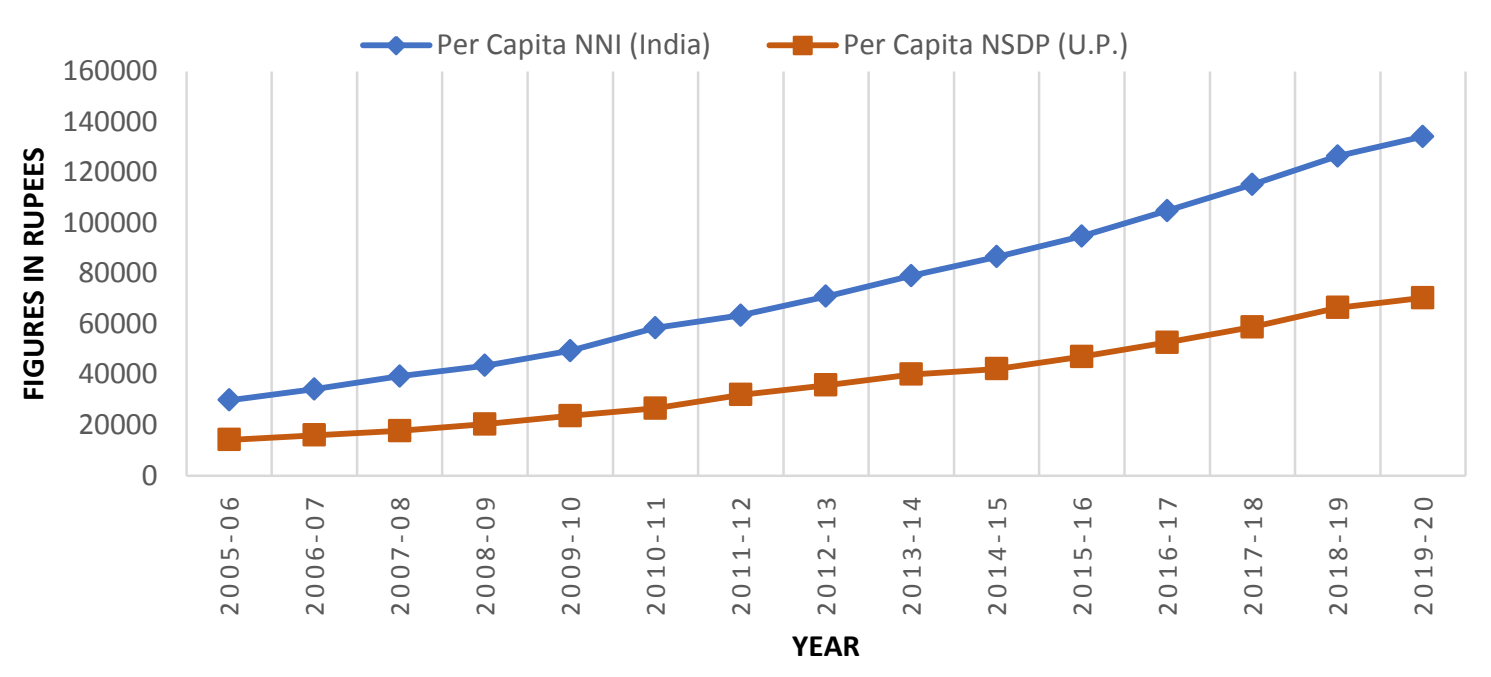

Source: Computed from Economic Survey 2020-21

Since independence, Uttar Pradesh's GSDP growth was almost equal to that of India (see table above) though per capita GSDP fell due to high population growth in comparison to India but since 1991 when the government of India changed its policies from inward looking to globalisation and liberalisation and the role of public sector diminished, Uttar Pradesh growth rate fell much behind that of India (because Southern, northern and western states of India moved ahead) but population growth remained higher than the average of India. Thus, Uttar Pradesh became a part of BIMARU states with the low economic and social infrastructure. With privatisation and liberalisation most of the southern and western states got a push to economic growth due to high foreign and private sector investment but Uttar Pradesh, Bihar and some other states remained backward because of low capex. After a decade of LPG policies, the FRBM act was implemented all over the nation along with Uttar Pradesh which limited the capacity of all states with strong rules on revenue deficit, primary deficit and fiscal deficit. As a poor state, the tax GSDP ratio of Uttar Pradesh was very limited. Most of its revenue and capital expenditure continued on the grants and fund devolution by different finance commissions. Thus arrives the growth versus debt sustainability debate. As mentioned in early part of the paper, it was Keynes who suggested 'The policy of greater public spending' which breaks low level income equilibrium trap from both the sides (1) It increases disposable capital expenditure affecting aggregate supply and also creates a conducive atmosphere for private sector/foreign sector creating linkage between economic growth and debt sustainability (Chapter 2 of economic survey 2020-21 clearly mention this rule). That is why in all OECD countries, one of the most important ratios considered for debt sustainability is not the debt GDP ratio but debt sustainability ratio. In case of Uttar Pradesh, the following table makes it clear that post FRBM, Uttar Pradesh has been most successful in keeping its fiscal deficit below $2 \%$ and has attained revenue surplus in most of the years and primary deficit has also been less than $1 \%$ i.e. It has successfully been able to maintain strict FRBM rates throughout 2005-19 but its growth of GSDP has not been matching with that of India or other states. The main question that becomes important in case of Uttar Pradesh is whether fiscal sustainability is all important and could growth be overlooked? 
Volume: 9 | Issue: 8 | August 2021 | Journal DOI: 10.36713/epra0713 | SJIF Impact Factor (2021): 8.047

Table 1: Fiscal Indicators of Uttar Pradesh

\begin{tabular}{|c|c|c|c|c|c|c|}
\hline YEAR & $\begin{array}{c}\text { Fiscal } \\
\text { Deficit }\end{array}$ & $\begin{array}{c}\text { Revenue } \\
\text { Deficit }\end{array}$ & $\begin{array}{c}\text { Primary } \\
\text { Deficit }\end{array}$ & $\begin{array}{c}\text { Total OL as a \% } \\
\text { of GSDP }\end{array}$ & $\begin{array}{l}\text { IP as a \% of } \\
\text { GSDP }\end{array}$ & $\begin{array}{c}\text { Market } \\
\text { Borrowings } 1\end{array}$ \\
\hline $2005-06$ & 3.44 & 0.43 & 0.38 & 52.2 & 3.1 & 19.9 \\
\hline 2006-07 & 2.86 & -1.46 & 0.29 & 52.5 & 3.1 & 19.1 \\
\hline 2007-08 & 3.6 & -0.9 & -0.22 & 49.9 & 2.8 & 34.5 \\
\hline 2008-09 & 4.62 & -0.42 & 0.67 & 46.9 & 2.6 & 50.2 \\
\hline $2009-10$ & 3.57 & -1.35 & 1.77 & 43.3 & 2.3 & 61.1 \\
\hline 2010-11 & 2.87 & -0.58 & 0.51 & 39.4 & 2.4 & 58.4 \\
\hline 2011-12 & 2.25 & -1.02 & -0.01 & 38.3 & 2.3 & 83.2 \\
\hline 2012-13 & 2.34 & -0.63 & 0.3 & 33.8 & 2.1 & 32.6 \\
\hline 2013-14 & 2.52 & -1.07 & 0.7 & 29.7 & 1.9 & 21.3 \\
\hline 2014-15 & 3.21 & -2.21 & 1.3 & 28.3 & 1.9 & 41.6 \\
\hline $2015-16$ & 5.22 & -1.28 & 3.3 & 31 & 1.9 & 43.3 \\
\hline 2016-17 & 4.49 & -1.63 & 2.33 & 33.9 & 2.1 & 67.9 \\
\hline 2017-18 & 2.02 & -0.91 & 0.1 & 36.7 & 2 & 93.7 \\
\hline 2018-19 & 2.38 & -1.91 & 0.21 & 35.4 & 1.9 & 94.6 \\
\hline 2019-20 & -0.66 & -4 & -2.72 & 34 & 2.1 & 83.2 \\
\hline $\begin{array}{c}\text { 2020-21 } \\
\text { (R.E.) }\end{array}$ & 4.17 & 0.68 & 2.19 & 33.9 & 2.3 & 86.8 \\
\hline $\begin{array}{c}\text { 2021-22 } \\
\text { (B.E.) }\end{array}$ & 4.17 & -1.07 & 2.17 & 33.1 & 2 & -- \\
\hline
\end{tabular}

OL: Outstanding Liabilities, IP: Interest Payment

Source: Uttar Pradesh's Budget Document, various years.

Economic theorists and practitioners now have come to almost unanimous conclusion that growth is most important. If growth is high, higher debt could be sustained. As per Economic Survey, Chapter 2, if GDP growth rate excludes interest payment rate there is nothing to worry on the ground of debt sustainability. Denoting primary deficit to GDP ratio (z) and debt to GDP ratio (d) one can say that debt is sustainable if $\mathrm{z}<=$ $(\mathrm{g}-\mathrm{r}) * \mathrm{~d}$

In case of India, the revenue of states comprises of two main sources: own tax revenue and share and grants from the Centre. Own resources of states differ because of economic activity and geographical topography. Central transfers depend upon various factors to bring horizontal and vertical balance among states. Uttar Pradesh has been the largest beneficiary from central transfers because of its population and geographical size. So, in case of Uttar Pradesh the ratio of own resources to central transfers has been around $30 \%$ to $70 \%$. It also used to get a lot of public investment projects since 1951 i.e., the formation of Planning Commission. Two important economic incidents impacted adversely the growth of Uttar Pradesh. Firstly, in 1991 the central government adopted liberal economic policy which reduced the expenditure on public sector. Secondly, FRBM act limited the capacity of states by fixing the limit of fiscal deficit. FRBM act in fact should have distinguished between Centre and States in fixing limit of different deficits because they have no control on monetary policy and no access to foreign borrowings. Generally, states have to depend upon public borrowing within their States and borrowings from RBI. Once the limit to fiscal deficit is fixed by FRBM, states were forced to limit their debt liabilities also. Uttar Pradesh being a backward state although receives a large share from central pool, had been borrowing heavily since 1991 to keep up the capital expenditure as private and foreign capital was not coming forward to Uttar Pradesh. The policy of high fiscal deficit led to higher debts and higher interest payments during 1991-2003.

\footnotetext{
${ }^{1}$ Growing market borrowings as a part of liabilities, always helps a state because interest on market borrowing is always less (at present it between 5\% to 6\%) than on other liabilities like provident fund which carries a rate of interest of $8 \%$ and above.
} 
Figure 2: Outstanding Liabilities and Interest Payments of U.P.

\section{Outstanding Liabilities \& Interest Payment of U.P. as \% of GSDP}

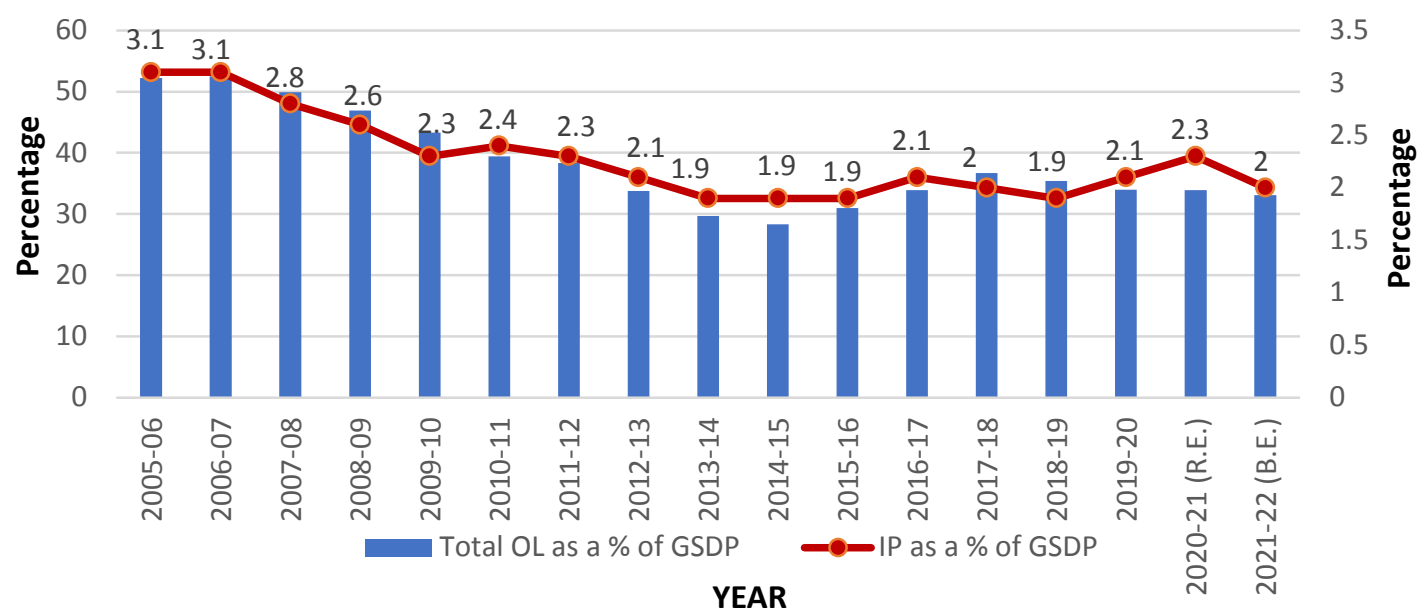

Source: Author's Computation based on data from RBI, Handbook of Statistics on Indian States, 2020.

One must remember that in 1992-93, the debt GSDP ratio was $24.66 \%$ which rose to $38.18 \%$ by 2003 but since 2005 there has been a general declining trend. Similarly, in case of interest payments on public debt there has also been a decline from around $2.5 \%$ in $2003-04$ to around $1.9 \%$ by 2015-16 (Table 1, Figure 2).

As per FRBM act, all states had to maintain a debt GSDP ratio below $46.9 \%$ by $2011-12$. All states did achieve this goal but Uttar Pradesh overshot the target and its debt-GSDP ratio was below 25\%. Revenue surplus has been achieved since 2007-08 and primary deficit has been under control (a minor slippage is seen in the year 2010 because of global recession). So, one can conclude that Uttar Pradesh has fully complied with all the FRBM targets rather overshot them in most years. This fact becomes important because Uttar Pradesh's GSDP growth was much slow during this period in comparison to most states and united India.

\section{FRBM AND UTTAR PRADESH}

The state implemented FRBM act in 2004 and amended it in 2011 and further in 2016. The fiscal deficit, revenue deficit and primary deficit are given below from the year 2005-06 to 2021-22 (Figure 3).

Figure 3: Fiscal Deficit, Revenue Deficit and Primary Deficit of Uttar Pradesh

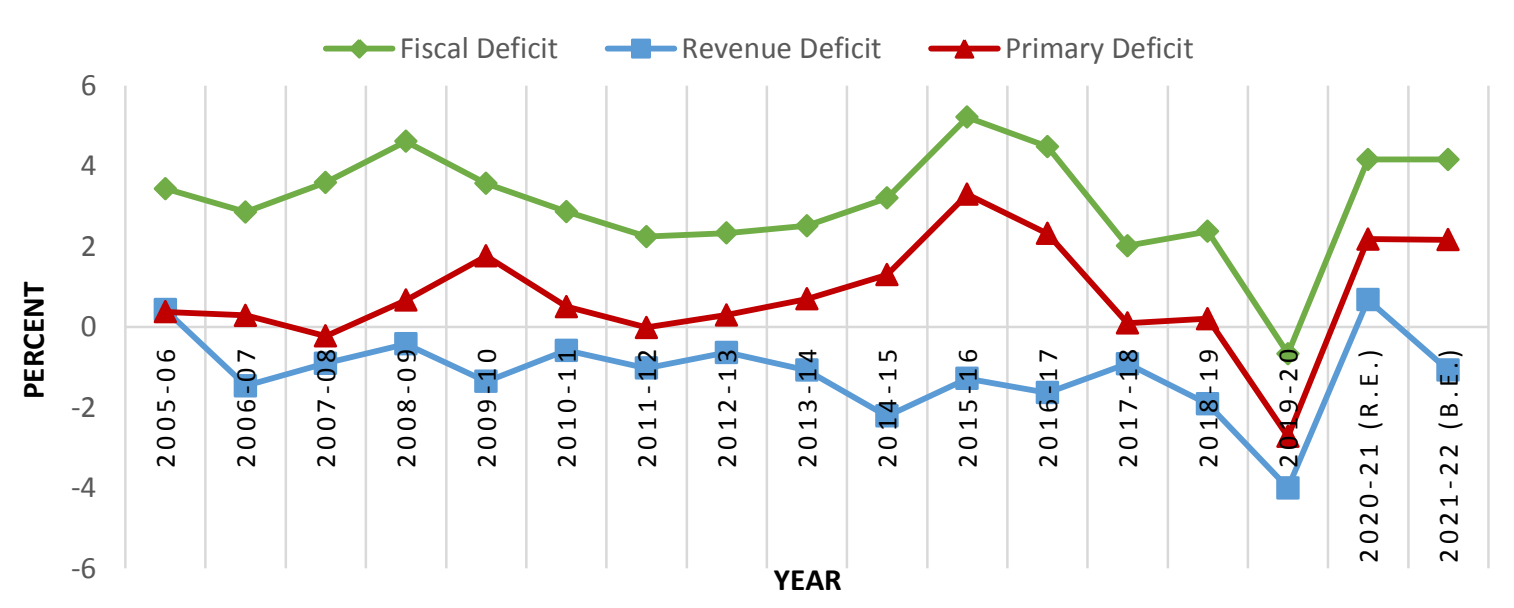

Source: Computed from RBI State Finances Report of various years

Uttar Pradesh has not been adhering to debt limits especially after 2016 and during pandemic. 
Volume: 9 | Issue: 8 | August 2021 | Journal DOI: 10.36713/epra0713 | SJIF Impact Factor (2021): 8.047

Table 2: Debt-GSDP Ratio and Fiscal Deficit of Uttar Pradesh as prescribed by FRBM and as amended (2011) by Uttar Pradesh and Actual Achievements

\begin{tabular}{|c|c|c|c|c|}
\hline Year & $\begin{array}{c}\text { Debt GSDP Ratio } \\
\text { prescribed by } \\
\text { FRBM }\end{array}$ & $\begin{array}{c}\text { Actual } \\
\text { Achievement }\end{array}$ & $\begin{array}{c}\text { Fiscal Deficit as } \\
\text { prescribed by FRBM } \\
\text { amended 2011 }\end{array}$ & $\begin{array}{c}\text { Actual } \\
\text { Achievement }\end{array}$ \\
\hline $\mathbf{2 0 1 1 - 1 2}$ & 46.9 & 33.6 & 3.0 & 2.1 \\
\hline $\mathbf{2 0 1 2 - 1 3}$ & 45.1 & 31.6 & 3.0 & 2.3 \\
\hline $\mathbf{2 0 1 3 - 1 4}$ & 43.4 & 30.0 & 3.0 & 2.5 \\
\hline $\mathbf{2 0 1 4 - 1 5}$ & 41.9 & 30.4 & 3.0 & 3.2 \\
\hline $\mathbf{2 0 1 5 - 1 6}$ & 31.0 & 32.3 & 3.0 & 5.1 \\
\hline $\mathbf{2 0 1 6 - 1 7}$ & 31.0 & 32.8 & 3.0 & 1.9 \\
\hline $\mathbf{2 0 1 7 - 1 8}$ & 30.05 & 32.0 & 3.0 & 2.4 \\
\hline $\mathbf{2 0 1 8 - 1 9}$ & 30.0 & 31.0 & 3.0 & 2.7 \\
\hline $\mathbf{2 0 1 9 - 2 0}$ & 29.5 & 31.1 & 3.0 & 4.7 \\
\hline $\mathbf{2 0 2 0 - 2 1}$ (R.E.) & 28.0 & 30.2 & 3.0 & 4.1 \\
\hline $\mathbf{2 0 2 1 - 2 2}$ (B.E.) & 28.0 & 29.2 & 3.0 & \\
\hline
\end{tabular}

Source: Uttar Pradesh Budget Documents of various years

Looking at the figures in the table, one finds out that Uttar Pradesh government had a lower public debt GSDP ratio between 2012-13 to 2017-18 and is marginally ahead. Even in the pandemic, the public debt GSDP ratio is only slightly ahead for revised and budget estimates (this could also be due to high GSDP estimates which are unlikely to be achieved in 2020-21 and 2021-22). The fiscal deficit also has been much lower than prescribed by amended FRBM act of Uttar Pradesh up to 2018-19 and has crossed the primary deficit prescribed ratio only in 2019-20 and during pandemic. Similarly, in the table 1 primary deficit and revenue deficit have been maintained and generally remained below the target. One can clearly conclude that the government of Uttar Pradesh has been complying with all fiscal ratios (2011 amendment) except in 2009-10 (due to global recession at pre-revised prescribed FRBM rules) and in pandemic period. All economic experts believe that during recessionary period, government has to be proactive to maintain aggregate demand. Now the question is whether compliance of fiscal responsibility budget management act of the state has effected growth of Uttar Pradesh adversely?

To measure growth is by no means easy, as economists and international institutions have taken various social economic variables to measure the same. Moreover, growth is a continuous process not any abstract thing. Earlier, only per capita income was considered. But now many socio-economic demographic variables are used to determine and compare growth between nations and on different times. In the following table a comparison of various indicators of growth have been done between Uttar Pradesh and India.

Table 3: Economic and Social Indicators of Uttar Pradesh and India as per XV Finance Commission

\begin{tabular}{|c|c|c|c|c|c|}
\hline \multicolumn{3}{|c|}{ Economic Indicators } & \multicolumn{3}{|c|}{ Social Indicators } \\
\hline & $\begin{array}{c}\text { Uttar } \\
\text { Pradesh }\end{array}$ & India & & $\begin{array}{c}\text { Uttar } \\
\text { Pradesh }\end{array}$ & India \\
\hline Per Capita GSDP & Rs 74,402 & Rs $1,40,422$ & $\begin{array}{l}\text { Children per women } \\
\text { (TFR) }\end{array}$ & 2.7 & 2.2 \\
\hline Tax GSDP Ratio & $7.2 \%$ & $6.3 \%$ & Literacy Rate & $67.7 \%$ & $73 \%$ \\
\hline \multirow[t]{5}{*}{ SDG Goals } & \multirow{5}{*}{$\begin{array}{c}\text { Score } 55 \\
\text { Rank } 24^{\text {th }} \\
\text { among States }\end{array}$} & \multirow[t]{5}{*}{ Score 62} & $\begin{array}{c}\text { Availability of toilets per } \\
\text { household }\end{array}$ & $45.8 \%$ & $61.1 \%$ \\
\hline & & & Life Expectancy (Years) & 65 & 69 \\
\hline & & & $\begin{array}{c}\text { Sex Ratio (females per } \\
1000 \text { males) }\end{array}$ & 912 & 943 \\
\hline & & & $\begin{array}{c}\text { Infant Mortality Rate } \\
\text { (deaths per } 1000 \text { live } \\
\text { births) }\end{array}$ & 43 & 32 \\
\hline & & & $\begin{array}{c}\text { Per Capita Health } \\
\text { Expenditure } \\
\text { (FY } 2019 \text { in Rs) }\end{array}$ & 807 & 1218 \\
\hline
\end{tabular}

Source: XV Finance Commission, Report - The States, Volume IV. 
A cursory glance through the table of comparison between Uttar Pradesh and India, one finds that in all socio-economic demographic features, Uttar Pradesh lacks far behind. Its per capita income is almost half of that of India. Literacy rate, life expectancy, infant mortality rate, sex ratio of Uttar Pradesh demonstrates it as a backward state. Many economic, infrastructural indicators are not being placed for brevity yet they are evident as no private sector large companies of textile, steel, cement or other manufacturing have been set up in Uttar Pradesh. In last few years, in Noida, Greater Noida, Modi Nagar and Meerut there has been some service industries (electronics, software and hardware) have come up. But Eastern region, Bundelkhand and Central region of Uttar Pradesh do not have any significant industry. The Uttar Pradesh government has begun with some ODOP programmes related to handloom and handicraft but no significant progress has been made till date. Unemployment rate is very high and that is why a large number of people migrate from Uttar Pradesh. So, it is evident that post-liberalisation period, Uttar Pradesh growth rate has been far from satisfactory especially in $21^{\text {st }}$ century. It could be because of variety of reasons like high population density, lack of skilled manpower, lack of economic infrastructure. But the most important fact is that due to low growth rate of state GSDP, the debt sustainability has also become a problem. Low growth of the state GSDP leads to low tax revenues, low investment and low growth. The balanced growth thesis or even the unbalanced growth thesis suggests heavy investment in all or leading sectors is required for high growth rate. Investment alone can lead to higher growth. The growth potential of Uttar Pradesh has to be tapped but how should it be done is the main question. Foreign and private investment is attracted not only by political will but also by economic and social infrastructure, economic policy and its implementation (governance), whatever could be the reason, the fact is that Uttar Pradesh needs a momentum to growth and probably Uttar Pradesh has missed a trick i.e., it could have opted for a high fiscal deficit for growth of industry and manufacturing between 2004-2017 instead of showing its commitment to fiscal prudence.

\section{CONCLUSION}

The question of GDP growth and fiscal sustainability shall be debated in proper context. With recession, every economy of the world follows Keynesian policies of money illusion to create an artificial demand which could generate positive sentiments for investors, consumers and policymakers while in pro-cyclic arena the problem of stability and fiscal sustainability gets greater importance. There is no set law, as to what amount of fiscal deficits are good in pro-cyclic period and counter cyclic period. World Bank policies of fixing deficit limits (3\% fiscal deficit, $0 \%$ primary deficit and a positive revenue surplus) cannot and should not be maintained in all periods. Washington Consensus was created at a point where most Latin American countries were facing debt repayment problems especially the foreign debt along with low GDP growth rate of 3\% to 4\%. In 1970s and up to 1990s the whole lot of developed countries were facing stagflation therefore monetized deficit was to be limited. In 1990s, Indian union and most states were also nearing the debt trap. Nearly $40 \%$ of the budget expenditure was on interest payments and no money was left for Capex. Similar was the case of states which were overburdened by salary payments and debt repayments. In 1991 when economy was opened, several southern and western states invited foreign capital as well as private capital and with better infrastructure both kind of investment increased which led to faster growth of state GSDP, own tax ratio and increased expenditure on social infrastructure. While Uttar Pradesh, Bihar, Odisha etc. lagged behind due to high population pressure and lack of infrastructure, industry and manufacturing. In this scenario FRBM act was enacted in all states irrespective of their contextual position. Uttar Pradesh adhered to FRBM regulation since 2004 and as amended in 2011 which did not allow the enhancement in Capex which was nearly $30 \%$ of total expenditure and a majority of it was in social infrastructure. Uttar Pradesh's public debt/State GSDP ratio was falling which limited its growth potential. ${ }^{2}$ In economic survey 2020-21, the debate of growth versus fiscal sustainability has been reopened while from 1991 to 2020 there was a concerted effort from central and state governments to maintain fiscal responsibility and Uttar Pradesh and Bihar led by generally the political parties different from the Centre have

\footnotetext{
${ }^{2}$ In pandemic 2019 as well as in global recession of 2008, gross debt in all OECD countries increased from around $30 \%$ of GDP to $40 \%$ of GDP. All the countries announced expansionary policies. In 2019 the government of Uttar Pradesh was forced to enhance public expenditure due to variety of reasons like large number of migrants coming back to Uttar Pradesh from all corners, the government had to feed them and also provide alternative subsistence employment, health infrastructure was to be improved, digitalisation was to make progress and tax revenue of the state and grants of Centre was being reduced. Uttar Pradesh had to opt for public debt which rose rapidly from around 5.65 trillion in 2020-21 to Rs.6.11 trillion (8\%) but more importantly the borrowing from the public is more than Rs.4.18 trillion by Uttar Pradesh government and its agencies according to Uttar Pradesh's annual budget surpassing the prescribed FRBM mandate to keep aggregate debt of GSDP by more than $4 \%$. This has been justified by 15 th finance commission and economic survey 2020-21.
} 
successfully maintained fiscal ratios within limits but are posting lower GSDP growth than most of the states. The question is, maintaining fiscal sustainability (especially in the case of states which does not impact price and exchange rate stability) is of greater importance or the objective of achieving growth is of greater importance? C. Rangarajan and D.K. Srivastava in 2005 maintained that a high growth rate can make debt sustainable, provided the terms of repayment (interest rate and time) are less than the growth rate. Therefore, it can be concluded that in the debate of fiscal sustainability and growth, growth should be given more importance in all times and not only in period of recession and especially in pandemic.

\section{REFERENCES}

1. Akram V. and Badri Narayan Rath, "Fiscal sustainability in India: evidence from Markov switching and threshold regression models", Emerald Insight, June 2021. https://www.emerald.com/insight/content/doi/10.1108/SEF-09-2018-0281/full/html

2. Arai Real, "Productive Government Expenditure and Fiscal Sustainability", FinanzArchiv / Public Finance Analysis Vol. 67, No. 4 (December 2011), pp. 327-351 (25 pages), Published By: Mohr Siebeck GmbH \& Co. KG, JSTOR. https://www.jstor.org/stable/41472631

3. Debt Sustainability Monitor (2021), Institutional Paper 143, February 2021, European Commission. https://ec.europa.eu/info/sites/default/files/economy-finance/ip143_en.pdf

4. Economic Survey (2020-21) Chapter 2, "Does Growth Lead to Debt Sustainability? Yes, But not Vice-Versa!". https://www.indiabudget.gov.in/economicsurvey/ebook_es2021/index.html

5. 'Fiscal Policy and Long-Term Growth' IMF Policy Paper, June 2015. https://www.imf.org/external/np/pp/eng/2015/042015.pdf

6. "Restoring Fiscal Sustainability: Lessons for the Public Sector", Public Governance Committee Working Party of Senior Budget Officials, OECD (2009)

https://www.oecd.org/governance/budgeting/44473800.pdf

7. Srivastava, D.K. (2020), "How far can India stretch its fiscal deficit to support economic growth?, Ernst \& Young, Economy Watch, September Issue, 2020.

https://www.ey.com/en_in/tax/economy-watch/how-far-can-india-stretch-its-fiscal-deficit-to-support-economicgrowth

8. Turner David and Francesca Spinelli (2009), "Interest-rate-growth differentials and government debt dynamics", OECD Journal - Economic Studies.

https://www.oecd.org/economy/growth/interest-rate-growth-differentials-and-government-debt-dynamics.pdf 